\title{
Production and Characterization of Intergeneric Hybrids between Dichroa febrifuga and Hydrangea macrophylla
}

\author{
Sandra M. Reed and Keri D. Jones ${ }^{1}$ \\ Floral and Nursery Plants Research Unit, U.S. National Arboretum, Agricultural Research Service, \\ U.S. Department of Agriculture, Tennessee State University Otis L. Floyd Nursery Research Center, \\ 472 Cadillac Lane, McMinnville, TN 37110
}

\author{
Timothy A. Rinehart \\ Southern Horticultural Laboratory, Agricultural Research Service, U.S. Department of Agriculture, \\ 810 Highway 26 West, Poplarville, MS 39470
}

\begin{abstract}
AdDitional INDEX wORDs. wide hybridization, bigleaf hydrangea, ploidy, SSRs, flow cytometry
Aвstract. The potential of producing an intergeneric hybrid between Dichroa febrifuga Lour. and Hydrangea macrophylla (Thunb.) Ser. was investigated. Reciprocal hybridizations were made between a $D$. febrifuga selection (GUIZ 48) and diploid ('Veitchii') and triploid ('Kardinal' and 'Taube') cultivars of H. macrophylla. Embryo rescue was employed for about one-third of the crosses that produced fruit, and the rest were allowed to mature on the plant and seedcollected and germinated. Reciprocal hybrids, which were verified with simple sequence repeat markers, were produced from both embryo rescue and seed germination and with both diploid and triploid $\boldsymbol{H}$. macrophylla cultivars. Hybrids were intermediate in appearance between parents, but variability in leaf, inflorescence, and flower size and flower color existed among the hybrids. A somatic chromosome number of $2 n=6 x=108$ was tentatively proposed for $D$. febrifuga GUIZ 48 . Chromosome counts and flow-cytometric measurements of nuclear DNA content indicated that some of the hybrids may be aneuploids, but neither analysis was definitive. Although hybrids with $\boldsymbol{H}$. macrophylla as the pistillate parent did not form pollen-producing anthers, $D$. febrifuga $\times H$. macrophylla hybrids had normal-appearing anthers that produced abundant pollen. $\mathrm{F} 2$ and $\mathrm{BC} 1$ progeny were obtained using $D$. febrifuga $\times$ 'Veitchii' hybrids. This work documents the first step in an effort to combine desirable horticultural features from D. febrifuga and $H$. macrophylla.
\end{abstract}

Dichroa febrifuga is an evergreen native to Nepal, southern China, and Southeast Asia, and it is cultivated both as an ornamental and a medicinal plant (Hinkley, 2005; Shumei and Bartholomew, 2001). A member of the Hydrangeaceae, it grows $1-2 \mathrm{~m}$ in height and width. Terminal panicles, ranging in width from 3 to $20 \mathrm{~cm}$, form in mid- to late summer. Inflorescences consist entirely of perfect flowers, which may be white, pink, or blue. The fruits ripen into bright blue berries that persist throughout winter. The plant is estimated to be hardy to U.S. Department of Agriculture (USDA) Cold Hardiness Zone 7 (Hinkley, 2005).

Hydrangea macrophylla is the most popular member of the Hydrangeaceae. It is a small, deciduous shrub native to Japan and Korea (McClintock, 1957). Variously known as bigleaf, florist, garden, or French hydrangea, H. macrophylla is cultivated both as a garden and a pot plant. The species is valued for its large, brightly colored inflorescences, which range in color from white to pink through blue, and which contain a combination of inconspicuous, perfect, and showy, imperfect flowers. Most cultivars of $H$. macrophylla are rated as hardy to USDA Cold Hardiness Zone 6 (Dirr, 1998). Although inflorescences may remain attractive for several months and a few cultivars develop red fall foliage, H. macrophylla typically provides no winter interest in the landscape.

Received for publication 26 June 2007. Accepted for publication 3 Oct. 2007. Mention of trade names of commercial products in the publication is solely for the purpose of providing specific information and does not imply recommendation or endorsement by the U.S. Department of Agriculture.

${ }^{1}$ Corresponding author. E-mail: Sandra.Reed@ars.usda.gov.
Flower color in H. macrophylla is dependent on cultivar and availability of aluminum in the soil (Takeda et al., 1985); because aluminum becomes less available as soil $\mathrm{pH}$ rises, flower color is related to soil $\mathrm{pH}$. Although a few cultivars will not produce blue flowers even in the presence of adequate aluminum (Dirr, 2004), the flowers of most cultivars will be blue under low soil $\mathrm{pH}$ conditions. When grown in a high $\mathrm{pH}$ soil, flowers of these cultivars will be pink. Because the components used in soilless media contain no aluminum, aluminum must be added during pot plant production in greenhouses and for containerized nursery plants if blue flower color is desired at the time of sale. Greenhouse producers typically apply aluminum sulfate every 2 weeks while monitoring soil acidity to ensure that $\mathrm{pH}$ levels do not drop to toxic levels (Bailey, 1989). Changes in flower color under different soil $\mathrm{pH}$ conditions have not been investigated in D. febrifuga; however, we have observed that the GUIZ 48 selection of this species produces blue flowers in the absence of aluminum.

Phylogenetic analyses of rbcL sequences in the Hydrangeaceae suggest a close relationship between genus Dichroa Lour. and H. macrophylla (Soltis et al., 1995). Simple sequence repeat (SSR) markers indicate $H$. macrophylla is more genetically similar to D. febrifuga than to other Hydrangea L. species (Rinehart et al., 2006). Morphological investigations support a close relationship between these two species (Hufford, 2001; Soltis et al., 1995).

Wide hybridization has resulted in a number of landscape plants that possess the best features of both parents (Dirr, 1998), but the same success has been very difficult in Hydrangea. 
Although hybrids between H. macrophylla and Hydrangea paniculata Sieb. were produced using in ovolo embryo rescue, the resulting plants were sterile and lacked vigor (Reed et al., 2001; Reed, 2004). H. macrophylla $\times$ Hydrangea arborescens L. hybrids were also produced via embryo rescue, following regeneration from callus derived from cotyledon tissue (Kudo and Niimi, 1999), but were aneuploid and apparently not of commercial value. Embryo rescue was used to produce putative H. macrophylla $\times$ Hydrangea quercifolia Bartr. hybrids (Kudo et al., 2002); however, the vigor and fertility of this putative hybrid are not known. Hydrangea arborescens $\times$ Hydrangea involucrata Sieb. hybrids were obtained without using in vitro procedures, but they have no commercial merit and do not appear to be fertile (Jones and Reed, 2006). A hybrid between H. involucrata and Hydrangea aspera D. Don, both of which are members of subsection Asperae, is available commercially but is not considered particularly desirable (Dirr, 2004). Two preliminary reports of hybridization between $H$. macrophylla and D. febrifuga have been published; however, they both lack details on techniques used and descriptions of hybrid progeny (Jones et al., 2006; Kardos et al., 2006).

The objective of this study was to produce and characterize hybrids between $H$. macrophylla and D. febrifuga. Desirable traits from $D$. febrifuga include evergreen foliage, persistent blue berries, ability to produce blue flowers independent of aluminum availability, and large individual flowers. In comparison, H. macrophylla is more cold hardy and has larger inflorescences than $D$. febrifuga, and the showy imperfect flowers found in H. macrophylla and most other member of this genus are absent from $D$. febrifuga. The long-term goal of this project is to develop plants exhibiting a combination of desirable traits from H. macrophylla and D. febrifuga.

\section{Materials and Methods}

INTERGENERIC HYBRIDIZATION. Dichroa febrifuga selection GUIZ 48 and three H. macrophylla cultivars (Kardinal, Taube, and Veitchii) were used in this study. The D. febrifuga selection used was acquired from Heronswood Nursery (Warminster, PA) and was described as being a clone collected in Guizhou Province, China, by P. Wharton of the University of British Columbia Botanical Garden. 'Veitchii' is a diploid $(2 n=2 x=$ $36)$, and 'Kardinal' and 'Taube' are triploids $(2 n=3 x=54)$ (Jones et al., 2007). Cross-pollinations were made between $D$. febrifuga and the three $H$. macrophylla cultivars during Summer 2005. 'Kardinal' was used only as the staminate parent, whereas reciprocal pollinations were made with 'Taube' and 'Veitchii'. Opened and immature flowers were removed from inflorescences intended as parents. Both male and female inflorescences were covered with a breathable plastic bag (DelStar Technologies, Middletown, DE). Flowers were emasculated $1 \mathrm{~d}$ before anticipated anthesis and pollinated 1-3 $\mathrm{d}$ following emasculation by touching newly dehisced anthers directly to stigmas. Female inflorescences were then re-covered with the breathable plastic bag for at least 2 weeks.

Because of past difficulties in creating interspecific hybrids using $H$. macrophylla, in ovolo embryo rescue was employed with about one-third of the pollinations that produced fruit. Ovaries were collected 63-68 d after pollination, placed in 70\% ethanol for $1 \mathrm{~min}$, followed by $20 \%$ sodium hypochlorite for $20 \mathrm{~min}$, and then rinsed twice with sterile distilled water. All enlarged, opaque ovules were excised from the ovaries in a laminar flow hood using a stereomicroscope and placed on Gamborg's B-5 media (Gamborg et al., 1968) supplemented with $2 \%$ sucrose. All media were adjusted to $\mathrm{pH} 5.7-5.8$ before autoclaving. Cultures were maintained at $25{ }^{\circ} \mathrm{C}$ in the dark for the first 2 weeks and then given a 16-h light/8-h dark photoperiod. Cultures were examined for germination at 2-week intervals for 6 weeks. Plants were transferred to a soilless medium and moved to the greenhouse as soon as they developed a root system. Numbers of surviving plants was determined $\approx 8$ months after removal from aseptic conditions.

The remaining two-thirds of the capsules remained on the plant until maturity, which was $\approx 20$ weeks after pollination. Seed were removed from capsules and stored at $4{ }^{\circ} \mathrm{C}$ for 2 months. Previously published seed-germination and seedlinghandling procedures were used (Jones and Reed, 2006). Fifty seeds were planted for all hybrids except $D$. febrifuga $\times H$. macrophylla 'Kardinal', for which only 20 seeds were available. Percent survival was determined $\approx 6$ months after seeds were sown.

SSRs. To verify hybridity, 86 putative hybrids and parents were compared using eight SSR loci that produced polymorphic data for H. macrophylla and Dichroa parents. SSR loci included in this study were STAB045_46, 111_112, 125_126, 157_158,307_308,321_322, 429_430, and 501_502 (Rinehart et al., 2006). DNA extraction, PCR amplification, and SSR analysis methods of Rinehart et al. (2006) were followed. Principal-coordinate analysis ( $\mathrm{PCoA}$ ) was performed using NTSys software (Rohlf, 1992). Plots were based on the allele-sharing distance matrix.

Miтotic Cytology. Root tips were immersed in $0.1 \mathrm{~mm}$ colchicine for $3 \mathrm{~h}$ at room temperature $\left(22^{\circ} \mathrm{C}\right)$, placed in $45 \%$ acetic acid for $10 \mathrm{~min}$ at $4{ }^{\circ} \mathrm{C}$, followed by $20 \mathrm{~s}$ in a solution of $45 \%$ acetic acid : $1 \%$ hydrochloric acid $(1: 1)$ at $60^{\circ} \mathrm{C}$. After they were rinsed in distilled water, root tips were soaked in $1 \%$ aceto-orcein. The meristematic region of the root tip was squashed in aceto-orcein, and chromosomes were counted. Ten metaphase cells from D. febrifuga and H. macrophylla 'Kardinal' and at least two cells from each of three hybrids were examined. Root tips were not collected from the other two H. macrophylla cultivars, as somatic chromosome numbers of 36 and 54 had previously been established for 'Veitchii' and 'Taube', respectively (Jones et al., 2007).

Flow Cytometry. Flow-cytometric measurements of nuclear DNA quantity were made from 86 verified hybrids, D. febrifuga, and H. macrophylla 'Kardinal', 'Taube', and 'Veitchii'. Pisum sativum L. 'Ctirad' $(2 \mathrm{C}=9.09 \mathrm{pg})$ was used in each sample preparation, and hybrid data were normalized against this internal reference (Doležel and Bartoš, 2005). About $0.5 \mathrm{~cm}^{2}$ of growing leaf tissue of the sample plant and of $P$. sativum were chopped for 30-60 $\mathrm{s}$ in a plastic petri dish containing $0.4 \mathrm{~mL}$ of extraction buffer (Partec CyStain ultraviolet Precise P Nuclei Extraction Buffer; Partec GmbH, Münster, Germany). The resulting extract was passed through a $30-\mu \mathrm{m}$ filter into a $3.5-\mathrm{mL}$ plastic tube, to which was added $1.6 \mathrm{~mL}$ of Partec CyStain ultraviolet Precise P Staining Buffer containing the fluorochrome 4',6-diamidino-2-phenylidole (DAPI). The relative fluorescence of the total DNA was measured for each nucleus using a Partec PA-1 ploidy analyzer (Partec $\mathrm{GmbH}$ ). For each sample, at least 5000 nuclei were analyzed, revealing a single peak with a $\mathrm{Cv}<5.0 \%$ for all but two samples. Twelve samples were processed twice, and data were statistically indistinguishable after normalization. 
Morphological COMParisons. Cuttings of all parents were made in Summer 2005, moved to 11.4-L containers, and placed in the same greenhouse conditions as the hybrids so that parents and progeny would be exposed to similar light and temperature conditions. No supplemental aluminum was added to the pine bark-based growing medium. Blade length and width and petiole length were measured on the first fully expanded leaf of parents and 38 hybrids in July 2006. Three leaves were measured on each plant and values averaged.

Inflorescence and flower measurements were made on parents and 31 hybrids. Using three inflorescences of each plant, the widest part of the inflorescence was measured and the number of flowers per inflorescence counted. Flower length and width were measured on five flowers of each plant. Flower color was recorded for all hybrids that flowered, and flowers were examined for presence of pistils and stamens. Berry color was not assessed, as all fruits resulting from open or controlled pollinations were removed at the end of the growing season.

Production of $\mathbf{F}_{\mathbf{2}}$ ANd BC $\mathbf{B}_{\mathbf{1}}$ Progeny. During Summer 2006, seven D. febrifuga $\times$ 'Veitchii' plants were used in $\mathrm{F}_{2}$ and $\mathrm{BC}_{1}$ crosses. Two hybrids were self-pollinated, and the others were intercrossed. Four hybrids were used in reciprocal backcrosses to parental species. Hybridizations were made as described for the $F_{1}$ cross, and all seeds were allowed to mature on plant. Seed germination followed previously published techniques (Jones and Reed, 2006). For the self-pollination, all 30 seeds obtained were tested for germination. Sixty seeds from each of five fullsib $\mathrm{F}_{2}$ crosses and for each $\mathrm{BC}_{1}$ hybrid were germinated.

\section{Results}

INTERGENERIC HYBRIDIZATIONS. Fruit was produced from all five parental combinations (Table 1). About two-thirds of the crosses produced fruit; averaged over all crosses, fruit set was similar in reciprocals. From all combinations of crosses, 97 ovaries were collected for embryo rescue and 199 were allowed to mature on the plants.

No enlarged, opaque ovules were found in the 12 ovaries of D. febrifuga $\times$ 'Taube' that were collected for embryo rescue; therefore, no cultures were initiated from this hybridization. Although none of the cultured ovules of D. febrifuga $\times$ 'Kardinal' germinated, plants were obtained following embryo rescue of 'Taube' $\times D$. febrifuga, 'Veitchii' $\times D$. febrifuga, and D. febrifuga $\times$ 'Veitchii' (Table 1). Numbers of plants obtained following embryo rescue of these three hybridizations ranged from 0.8 to 1.4 per ovary; $63 \%$ to $93 \%$ of these plants were still alive $\approx 8$ months after transfer from aseptic conditions.

Seeds were obtained from all five hybridizations (Table 1). An average of 12 seeds per fruit were obtained when $\mathrm{H}$. macrophylla was used as the pistillate parent. Only $6 \%$ of 'Taube' $\times D$. febrifuga seeds germinated, and all seedlings died within 1 month of germination. Seed germination was also low for 'Veitchii' $\times D$. febrifuga, but $80 \%$ of these seedlings were still alive $\approx 6$ months after seeding. When $D$. febrifuga was used as the pistillate parent, a mean of five seeds were obtained from each mature fruit. Only $19 \%$ of the $D$. febrifuga $\times$ H. macrophylla seeds germinated, but $74 \%$ of the plants survived for at least 6 months.

Viable plants were obtained using both embryo rescue and seed germination only from reciprocal hybridizations of $D$. febrifuga and 'Veitchii'. For D. febrifuga $\times$ 'Veitchii', 0.7 viable plants were obtained per culture or seed capsule. The two procedures also had similar success rates for the reciprocal hybrid, where 1.3 viable plants were obtained per ovary cultured and 1.2 viable plants per capsule were produced following seed germination.

SSR ANALYSIS OF HYBRIDITY. SSR markers verified hybridity in 86 plants obtained from hybridization of H. macrophylla and D. febrifuga. All hybrids contained at least one allele from each parent for all loci except three hybrids between 'Veitchii' and D. febrifuga that failed to produce data at the STAB501_502 locus. Differences in allele frequencies based on the direction of the crosses were not observed. Inheritance of individual $H$. macrophylla alleles at a single locus fit Mendelian expectations for gene segregation. For example, 'Veitchii' is polymorphic at the STAB321_322 locus, and hybrids between 'Veitchii' and D. febrifuga segregated $52 \%: 48 \%$ at this locus. Dichroa samples produced from one to three alleles, depending on the

Table 1. Comparison of embryo rescue and seed germination for production and survival of hybrids between Dichroa febrifuga GUIZ 48 and three cultivars of Hydrangea macrophylla.

\begin{tabular}{|c|c|c|c|c|c|c|c|c|c|}
\hline \multirow[b]{2}{*}{ Hybridization } & \multirow[b]{2}{*}{$\begin{array}{c}\text { Crosses } \\
\text { made } \\
\text { (no.) }\end{array}$} & \multirow[b]{2}{*}{$\begin{array}{c}\text { Crosses } \\
\text { producing } \\
\text { fruit }(\%)\end{array}$} & \multicolumn{3}{|c|}{ Embryo rescue $^{z}$} & \multicolumn{4}{|c|}{ Seed germination ${ }^{y}$} \\
\hline & & & $\begin{array}{c}\text { Ovaries } \\
\text { used } \\
\text { (no.) }\end{array}$ & $\begin{array}{c}\text { Plants } \\
\text { obtained/ovary } \\
\text { cultured (no.) }\end{array}$ & Survival $(\%)$ & $\begin{array}{c}\text { Fruit } \\
\text { harvested } \\
\text { (no.) }\end{array}$ & $\begin{array}{l}\text { Seeds/fruit } \\
\text { (no.) }\end{array}$ & $\begin{array}{c}\text { Seed } \\
\text { germination } \\
(\%)\end{array}$ & $\begin{array}{l}\text { Survival } \\
(\%)\end{array}$ \\
\hline 'Kardinal' & 70 & 31 & 7 & 0 & - & 15 & 2.5 & 30 & 83 \\
\hline D. febrifuga $\times$ H. macrophylla & & & & & & & & & \\
\hline 'Taube' & 61 & 61 & - & - & - & 25 & 3.2 & 16 & 75 \\
\hline $\begin{array}{l}\text { H. macrophylla 'Taube' } \times \\
\text { D. febrifuga }\end{array}$ & 83 & 92 & 25 & 1.2 & 63 & 51 & 9.5 & 6 & 0 \\
\hline $\begin{array}{l}\text { H. macrophylla 'Veitchii' } \times \\
\quad \text { D. febrifuga }\end{array}$ & 132 & 45 & 20 & 1.4 & 93 & 40 & 14.9 & 10 & 80 \\
\hline
\end{tabular}

${ }^{\mathrm{z}}$ Ovaries harvested 9-10 weeks after pollination and cultured on Gamborg's B-5 media (Gamborg et al., 1968). Percent survival based on number of plants still living $\approx 8$ months after transfer from aseptic conditions.

${ }^{\mathrm{y}}$ Fruit allowed to mature on plant. Fifty seeds were planted for all hybrids except $D$. febrifuga $\times H$. macrophylla 'Kardinal', for which only 20 seeds were available. Percent survival based on number of plants still living $\approx 6$ months after seeds were sown. 
locus and showed distorted patterns of inheritance when more than one allele size was present, suggesting a higher ploidy level. A 2D scatter plot from a principal-coordinate analysis (PCoA) showed clear separation between the parents and the progeny, with hybrids clustering on the basis of their respective $H$. macrophylla parent (Fig. 1). PCoA explains $87.0 \%$ of the total variation, with $\mathrm{C} 1$ and $\mathrm{C} 2$ axes representing $51.0 \%$ and $36.0 \%$, respectively.

Chromosome counts and FLow CYTOMETRY. 'Kardinal' had 54 chromosomes, which confirmed previous flow-cytometric data indicating it to be triploid (Jones et al., 2007). Obtaining an accurate chromosome count from D. febrifuga was difficult because of the large number of chromosomes present. At least 104 chromosomes were counted in all cells observed, but the two leastambiguous cells appeared to have 108 chromosomes (Fig. 2). All hybrid cells examined had at least one area of overlapping chromosomes, making it impossible to obtain unequivocal chromosome counts. A minimum of 71 chromosomes were identified in two hybrids, which were from reciprocal crosses involving 'Veitchii' as the $H$. macrophylla parent. A $D$. febrifuga $\times$ 'Taube' plant had a minimum of 78 chromosomes, whereas a 'Taube' $\times D$. febrifuga plant had at least 83 chromosomes.

Flow-cytometric analysis indicated that $H$. macrophylla 'Kardinal' and 'Taube' had 7.5 pg of nuclear DNA and that 'Veitchii' had 4.7 pg (Table 2). With 16.9 pg of DNA, D. febrifuga GUIZ 48 had $\approx 3.5$ times the amount of nuclear DNA of 'Veitchii' and 2.2 times the amounts of 'Kardinal' and 'Veitchii'. Total nuclear DNA in the hybrids ranged from 10.5 to $13.3 \mathrm{pg}$. On average, hybrids involving 'Taube' or 'Kardinal' had more nuclear DNA than those in which 'Veitchii' had been used as the $H$. macrophylla parent; however, there was an overlap in the range of amounts of nuclear DNA between hybrids that had a diploid or triploid $H$. macrophylla parent.

Morphological measurements. Leaf blades of D. febrifuga were slightly shorter and considerably narrower than were those of H. macrophylla 'Kardinal', 'Taube', and 'Veitchii' (Table 3 ). While the $H$. macrophylla cultivars had leaf blade length-to-width ratios ranging from 1.1 to 1.4 , blades of $D$. febrifuga were more than twice as long as wide. The petioles of D. febrifuga were noticeably shorter than those of 'Kardinal' and 'Taube' and slightly shorter than those of 'Veitchii'. The hybrids exhibited variation in all leaf dimensions measured, but variability was greatest for blade length and width (Table 3 ). In general, hybrid leaf dimensions were intermediate to the parents, and no major differences between reciprocals were observed.

Mean inflorescence width was much larger in the three $H$. macrophylla cultivars than in D. febrifuga (Table 3). The $H$. macrophylla inflorescences contained 10-20 times more flowers than those of $D$. febrifuga; however, individual flower length and width were greater in D. febrifuga than in the H. macrophylla cultivars. Considerable variability was present within each hybrid population for all floral measurements. In most cases, the floral measurements of hybrids were intermediate

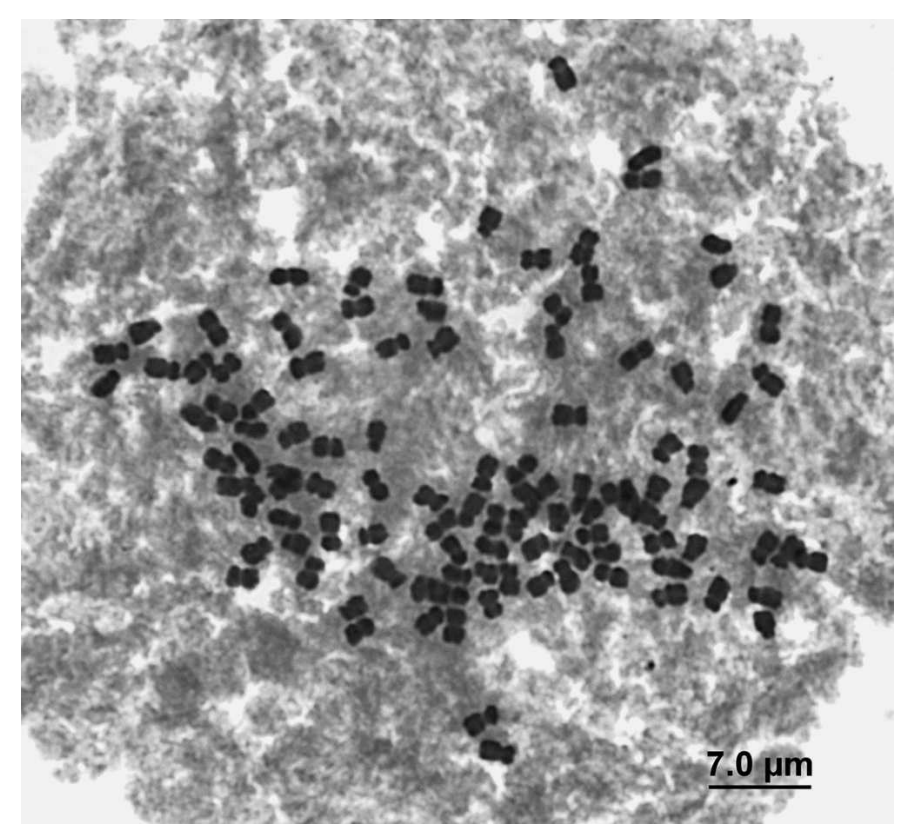

Fig. 2. Root tip cell from Dichroa febrifuga GUIZ 48 with 108 chromosomes. 
Table 2. Amount of total nuclear DNA in Dichroa febrifuga GUIZ 48, three Hydrangea macrophylla cultivars, and their hybrids

\begin{tabular}{|c|c|c|c|}
\hline \multirow[b]{2}{*}{ Plant } & \multirow{2}{*}{$\begin{array}{c}\text { Hybrids } \\
\text { examined (no.) }\end{array}$} & \multicolumn{2}{|c|}{ Total nuclear DNA ${ }^{z}$} \\
\hline & & Mean \pm SE (pg) & Range (pg) \\
\hline \multicolumn{4}{|l|}{ Parents } \\
\hline D. febrifuga & - & 16.9 & - \\
\hline H. macrophylla 'Kardinal' & - & 7.5 & - \\
\hline H. macrophylla 'Taube' & - & 7.5 & - \\
\hline H. macrophylla 'Veitchii' & - & 4.7 & - \\
\hline \multicolumn{4}{|l|}{ Hybrids } \\
\hline D. febrifuga $\times H$. macrophylla 'Kardinal' & 5 & $11.7 \pm 0.2$ & $11.1-12.1$ \\
\hline D. febrifuga $\times$ H. macrophylla 'Taube' & 6 & $12.6 \pm 0.2$ & $12.0-13.3$ \\
\hline D. febrifuga $\times$ H. macrophylla 'Veitchii' & 27 & $10.7 \pm 0.0$ & $10.5-10.9$ \\
\hline H. macrophylla'Taube' $\times D$. febrifuga & 18 & $11.8 \pm 0.1$ & $11.0-12.7$ \\
\hline H. macrophylla 'Veitchii' $\times D$. febrifuga & 30 & $11.0 \pm 0.0$ & $10.6-11.5$ \\
\hline
\end{tabular}

${ }^{\mathrm{z}}$ Total nuclear DNA estimated through flow-cytometric analysis of DAPI-stained nuclei.

macrophylla parental cultivars grown in the same potting medium and under the same conditions as the hybrids.

The flowers of the H. macrophylla $\times D$. febrifuga hybrids contained either no or petaloid stamens (Fig. 3B,D). In contrast, hybrids in which D. febrifuga was used as the pistillate parent contained normal-appearing stamens, most of which released copious amounts of pollen (Fig. 3A,C). None of the hybrids possessed the large, showy, imperfect flowers found in H. macrophylla.

Production of $F_{2}$ and BC $_{1}$ PROGENY. Viable seeds were produced from all $D$. febrifuga $\times$

to those of the parents or were similar to that of the parent with the smaller measurement; however, the inflorescences of the H. macrophylla $\times D$. febrifuga hybrids were smaller than those of the smallest parent. In general, the D. febrifuga $\times H$. macrophylla hybrids had larger inflorescences and flowers and more flowers per inflorescence than did the reciprocal hybrids.

Flower color and morphology were examined in 50 hybrids. Although one 'Veitchii' $\times D$. febrifuga plant had white flowers, the remaining hybrids had flower colors ranging from pink to blue (Fig. 3A-C). At least half of the plants of all groups of hybrids had blue or purple flowers (Table 3 ). The only group that did not produce any pink flowers was D. febrifuga $\times$ 'Veitchii'. Many of the hybrids had darkly colored stigmas, which were very noticeable when paired with light-colored sepals (Fig. 3D). No blue flowers were found on the $H$.
'Veitchii' $\mathrm{F}_{2}$ and $\mathrm{BC}_{1}$ crosses (Table 4 ). Only $\approx 1$ seed was obtained from each self-pollinated fruit, but the number of seeds per fruit ranged from 22 to 80 among the full-sib $\mathrm{F}_{2}$ and $\mathrm{BC}_{1}$ crosses. $\mathrm{F}_{2}$ seeds obtained through self-pollination or from crosses of full sibs had similar germination rates. Germination ranged from $13 \%$ to $62 \%$ among the different $\mathrm{BC}_{1}$ crosses.

\section{Discussion}

Despite previous difficulties in producing Hydrangea interspecific hybrids (Kudo and Niimi, 1999; Kudo et al., 2002; Reed et al., 2001), reciprocal hybrids between H. macrophylla and D. febrifuga were easily obtained using both diploid and triploid cultivars of $H$. macrophylla. Although embryo rescue was successful in producing the hybrids, it proved unnecessary

Table 3. Leaf, inflorescence and flower size and flower color in Dichroa febrifuga GUIZ 48, three cultivars of Hydrangea macrophylla, and their hybrids

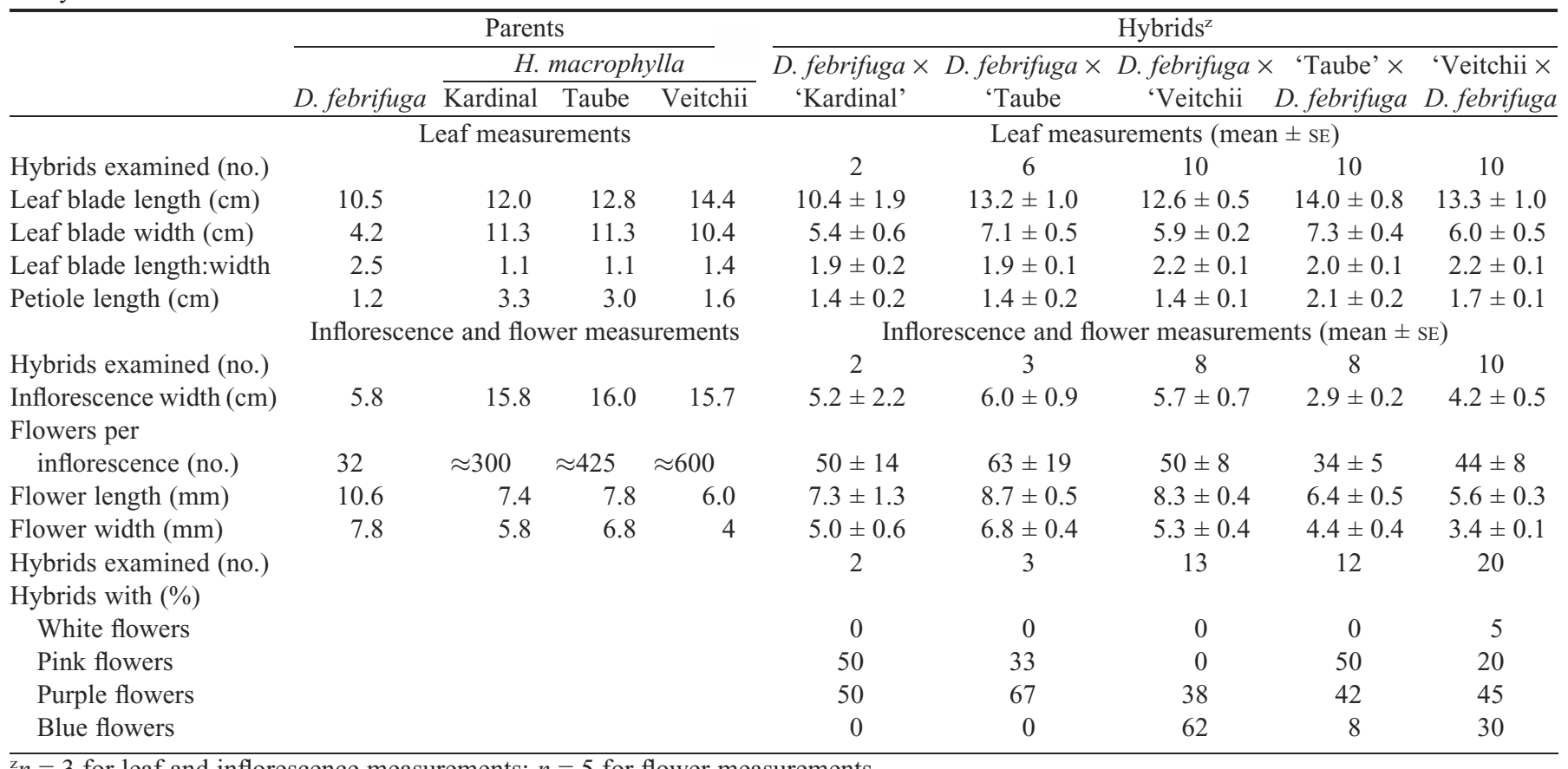

${ }^{z_{n}} n=3$ for leaf and inflorescence measurements; $n=5$ for flower measurements. 

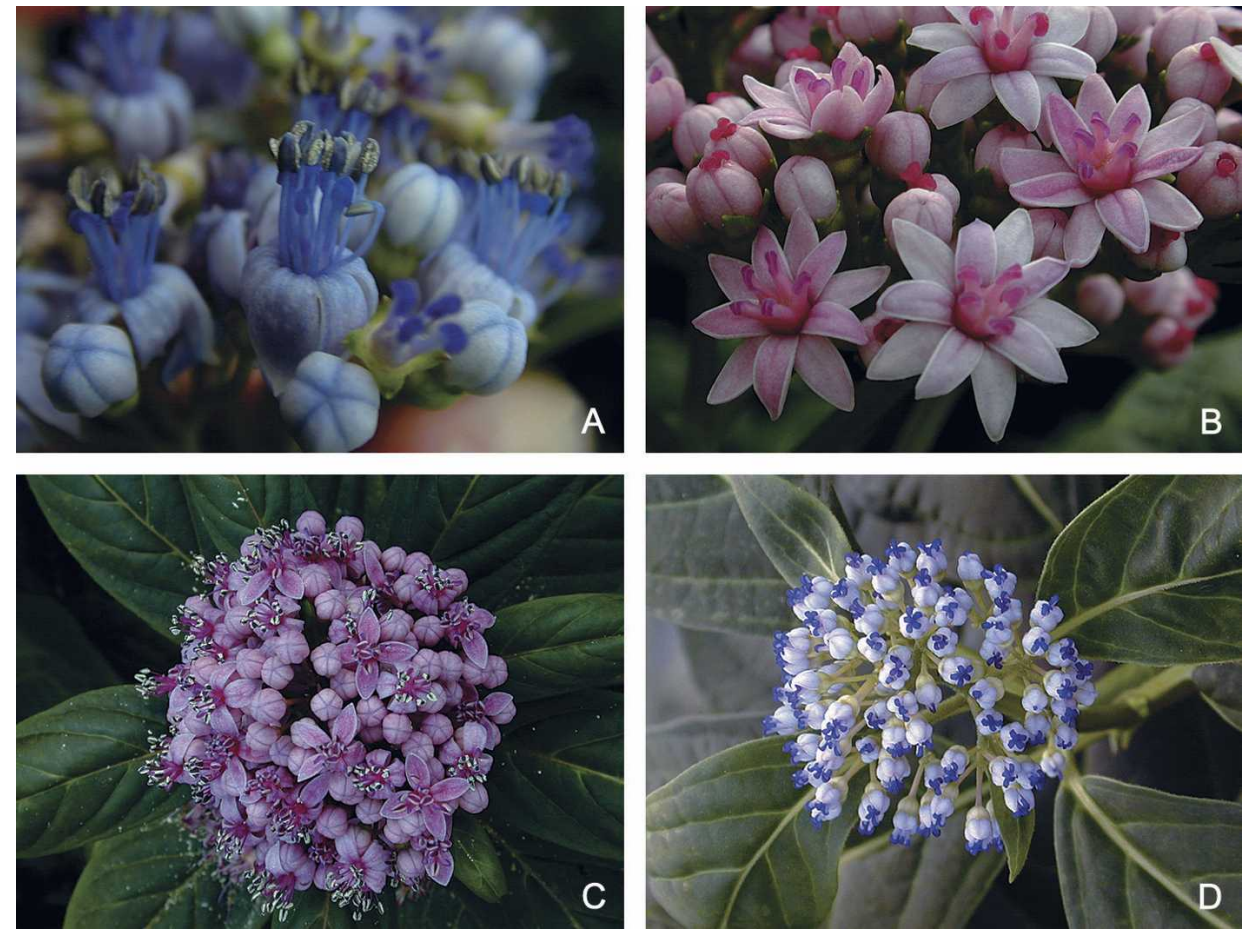

Fig. 3. Differences in flower color and morphology in hybrids of Dichroa febrifuga GUIZ 48 and Hydrangea macrophylla. (A) D. febrifuga $\times$ H. macrophylla 'Veitchii' hybrid with blue flowers and pollen-bearing anthers; (B) H. macrophylla 'Taube' $\times$ D. febrifuga hybrid with pink flowers and petaloid stamens; (C) D. febrifuga $\times$ H. macrophylla 'Veitchii' plant with light purple flowers and abundant pollen visible on anthers; (D) H. macrophylla 'Veitchii' $\times D$. febrifuga hybrid with sepals and stigmas of contrasting color and no stamens.

Table 4. Production of $\mathrm{F}_{2}$ and $\mathrm{BC}_{1}$ progeny from Dichroa febrifuga GUIZ $48 \times$ Hydrangea macrophylla 'Veitchii' $\mathrm{F}_{1}$ hybrids.

\begin{tabular}{|c|c|c|c|c|}
\hline Hybridization & $\begin{array}{l}\text { Crosses } \\
\text { made } \\
\text { (no.) }\end{array}$ & $\begin{array}{l}\text { Crosses } \\
\text { producing } \\
\text { fruit }(\%)\end{array}$ & $\begin{array}{l}\text { Seeds/fruit } \\
\text { (no.) }\end{array}$ & $\begin{array}{l}\text { Seed } \\
\text { germination } \\
(\%)^{\mathrm{z}}\end{array}$ \\
\hline \multicolumn{5}{|l|}{$\mathrm{F}_{2}$} \\
\hline Self-pollination & 56 & 41.1 & 1.3 & 36.7 \\
\hline Full-sib crosses & 392 & 45.2 & 26.5 & 24.9 \\
\hline \multicolumn{5}{|l|}{$\mathrm{BC}_{1}$} \\
\hline $\begin{array}{l}\text { H. macrophylla } \times(\text { D. febrifuga } \times \\
\text { H. macrophylla 'Veitchii' }) \\
(\text { D. febrifuga } \times \text { H. macrophylla 'Veitchii' }) \times\end{array}$ & 26 & 65.4 & 27.9 & 31.7 \\
\hline H. macrophylla & 68 & 100.0 & 80.0 & 13.3 \\
\hline $\begin{array}{l}\text { D. febrifuga } \times(D \text {. febrifuga } \times H . \\
\quad \text { macrophylla 'Veitchii') } \\
(\text { D. febrifuga } \times H \text {. macrophylla 'Veitchii') } \times\end{array}$ & 103 & 35.0 & 50.0 & 61.7 \\
\hline D. febrifuga & 88 & 100.0 & 22.0 & 25.0 \\
\hline
\end{tabular}

${ }^{\mathrm{z}}$ Number of seeds planted for germination test: $\mathrm{BC}_{1}$ crosses $=60$ seeds, $\mathrm{F}_{2}$ self-pollination $=30$ seeds, $\mathrm{F}_{2}$ full-sib crosses $=300$ seeds.

as hybrids were also obtained following germination of seeds that had been allowed to mature on the plant. However, embryo rescue was the only successful method for one of the three hybrid combinations in which $D$. febrifuga served as the pistillate parent. The embryo rescue procedure employed was originally developed for H. macrophylla (Reed, 2000); adjustments in media or time of collection of ovaries for culture may have improved success with D. febrifuga $\times H$. macrophylla. One hybrid combination failed to produce viable plants when seed germination was employed; however, this could have been the result of inadequate sampling because only 50 seeds were used for the germination test. For the two hybrid combinations that were obtained from both embryo rescue and seed germination, numbers of viable plants obtained per culture or fruit were similar for both techniques. All plants tested were verified as hybrids using SSR markers.

We are tentatively proposing $2 n=$ $6 x=108$ as the chromosome number for D. febrifuga GUIZ 48. Not only was this the count from the leastambiguous cells, but gametic chromosomes counts from other D. febrifuga plants indicate $n=18$ as the basic chromosome number for the species (Goldblatt, 1981). Flowcytometric data also support a high ploidy level for this clone as it was found to have more than three times the amount of nuclear DNA as did diploid H. macrophylla cultivars. We have preliminary flow-cytometric data that indicate that some of the other commercially available $D$. febrifuga cultivars and selections have considerably less total nuclear DNA than does GUIZ 48. We are currently investigating the chromosome number of these other clones; if diploid or tetraploid forms of D. febrifuga are found, they will be tested for hybridization with H. macrophylla.

There appears to be variation in chromosome number among individual hybrid plants; however, root tips were collected from a limited number of plants, only a few cells were observed from individual plants, and most counts were not clear-cut. Flow-cytometric data indicate several hybrids have more than $10.8-10.9 \mathrm{pg}$ of DNA, which is the amount that would be expected from the union of an $n$ gamete from $H$. macrophylla and a $3 n$ gamete from D. febrifuga. The largest amounts of nuclear DNA were observed in hybrids involving 'Kardinal' and 'Taube' as the H. macrophylla parent, which may be the result of aneuploid or $2 n$ gametes produced from these triploid cultivars. However, all flow-cytometric results should be interpreted with caution because DAPI has a higher affinity for AT than for GC bps and is less accurate than are DNA-intercalating fluorochromes such as propidium iodide (Doležel and Bartoš, 2005).

In general, hybrids were intermediate in appearance between parents, but variation was noted within each group of hybrids. 
Because both parental species are allogamous, some of this variation could be the result of segregation of heterozygous loci. In addition, because at least one parent of each hybrid is a polyploid, it is also possible that some of the variation results from different aneuploid cytotypes.

The most interesting morphological observations made involved hybrid flower color and form. About $30 \%$ of the hybrids had blue flowers, and an additional $43 \%$ had purple flowers, even though no supplemental aluminum had been added to the growing medium. Blue flower color was most common among plants obtained from hybridizations of $D$. febrifuga and 'Veitchii', a lacecap cultivar with white showy and violet or blue inconspicuous flowers (Dirr, 2004). Because blue flower color in the absence of aluminum is one of the desirable traits from $D$. febrifuga, the presence of blue- and purple-flowered $F_{1}$ progeny is promising. None of the hybrids had the showy, imperfect flowers that are typical of H. macrophylla, but this trait may be recovered in advanced-generation progeny. Although hybrids in which $H$. macrophylla served as the pistillate parent did not possess functional stamens, most plants of the reciprocal hybrid had stamens that produced large amounts of pollen.

Transfer of chromosomes from one species into the cytoplasm of another species following interspecific hybridization and recurrent backcrossing has resulted in cytoplasmic male sterility in many plant genera. This condition is referred to as "alloplasmic male sterility" (Kaul, 1988) and is often expressed as modification of stamens into petaloid or stigmatoid structures. Alloplasmic male sterility has been associated with impaired mitochondrial activity due to a poor cooperation between cytoplasmic and nuclear genomes either at the protein or the RNA level (Hakansson and Glimelius, 1991). It is possible that the petaloidy observed in $H$. macrophylla $\times D$. febrifuga hybrids is related to difference in ploidy level between the parental species. In the H. macrophylla $\times D$. febrifuga hybrids, D. febrifuga contributes three times more nuclear genetic material than the cytoplasmic parent, which may create an imbalance between cytoplasmic and nuclear genes. This imbalance would not exist in the reciprocal hybrid, in which the higher ploidy level parent contributed the cytoplasm.

Both $\mathrm{F}_{2}$ and $\mathrm{BC}_{1}$ progeny were obtained from $D$. febrifuga $\times$ 'Veitchii' hybrids. $\mathrm{F}_{2}$ seed set was considerably lower when hybrids were self-pollinated rather than crossed to full sibs. Self-incompatibility has been documented in $H$. macrophylla (Reed, 2005) and inferred for D. febrifuga (Hinkley, 2005). Additional $\mathrm{F}_{2}$ crosses are necessary to determine if the low seed set that we observed following self-pollination of $D$. febrifuga $\times$ 'Veitchii' hybrids was due to self-incompatibility or to inadequate sampling. Although seed set and germination varied among $\mathrm{BC}_{1}$ crosses, reciprocal backcrosses to both parental species produced viable progeny.

This research solidifies the close relationship between $H$. macrophylla and D. febrifuga and supports recent phylogenetic research (Hufford, 2001; Rinehart et al., 2006; Soltis et al., 1995), pointing to their close evolutionary relationship. From a breeding standpoint, it is encouraging that the ability to produce blue flowers in the absence of aluminum is expressed in the $F_{1}$ generation. Several of the hybrids obtained are attractive plants; however, data on cold hardiness, pest resistance, and growth habit in landscape settings are needed before their ornamental merit can be fully assessed. Because we were able to obtain advanced-generation progeny from the D. febrifuga $\times$ 'Veitchii' hybrid, we are optimistic that it and other $D$. febrifuga $\times H$. macrophylla hybrids will serve as the basis for the development of superior plants with unique combinations of ornamental traits.

\section{Literature Cited}

Bailey, D.A. 1989. Hydrangea production. Timber Press, Portland, OR.

Dirr, M.A. 1998. Manual of woody landscape plants. Their identification, ornamental characteristics, culture, propagation and uses. Stipes Publ., Champaign, IL.

Dirr, M.A. 2004. Hydrangeas for American gardens. Timber Press, Portland, OR.

Doležel, J. and J. Bartoš. 2005. Plant DNA flow cytometry and estimation of nuclear genome size. Ann. Bot. (Lond.) 95:99110 .

Gamborg, O.L., R.A. Miller, and K. Ojima. 1968. Nutrient requirements of suspension cultures of soybean root cells. Exp. Cell Res. 50:151-158.

Goldblatt, P. 1981 (ed.). Index to plant chromosome numbers 19751978. Missouri Bot. Garden Press, St. Louis.

Hakansson, G. and K. Glimelius. 1991. Extensive nuclear influence on mitochondrial transcription and genome structure in male fertile and male-sterile alloplasmic Nicotiana materials. Mol. Gen. Genet. 229(3):380-388.

Hinkley, D.J. 2005. Plants of merit. Dichroa febrifuga. Horticulture 102(6):79.

Hufford, L. 2001. Ontogeny and morphology of the fertile flowers of Hydrangea and allied genera of tribe Hydrangeeae (Hydrangeaceae). Bot. J. Linnean Soc. 137:139-187.

Jones, K.D. and S.M. Reed. 2006. Production and verification of Hydrangea arborescens 'Dardom' $\times H$. involucrata hybrids. HortScience 41:564-566.

Jones, K.D., S.M. Reed, and T.A. Rinehart. 2006. Wide crosses in the Hydrangeaceae: Dichroa febrifuga $\times$ Hydrangea macrophylla. Proc. Southern Nursery Assn. Res. Conf. 51:577-579.

Jones, K.D., S.M. Reed, and T.A. Rinehart. 2007. Analysis of ploidy level and its effects on guard cell length, pollen diameter and fertility in Hydrangea macrophylla. HortScience 42: 483-488.

Kardos, J.H., C.D. Robacker, M.A. Dirr, and T.A. Rinehart. 2006. Production and verification of hybrids from Hydrangea macrophylla $\times$ $H$. angustipetala and H. macrophylla $\times$ Dichroa febrifuga. Proc. Southern Nursery Assn. Res. Conf. 51:570-572.

Kaul, M.L.H. 1988. Male sterility in higher plants. Springer, Berlin. Kudo, N., Y. Kimura, and Y. Niimi. 2002. Production of interspecific hybrid plants by crossing Hydrangea macrophylla f. hortensia (Lam.) Rehd. and H. quercifolia Bartr. through ovule culture. Hort. Res. Japan 1:9-12.

Kudo, N. and Y. Niimi. 1999. Production of interspecific hybrid plants through cotyledonary segment culture of embryos derived from crosses between Hydrangea macrophylla f. hortensia (Lam.) Rehd. and H. arborescens L. J. Jpn. Soc. Hort. Sci. 68:803-809.

McClintock, E. 1957. A monograph of the genus Hydrangea. Proc. California Acad. Sci. 29:147-256.

Reed, S.M. 2000. Development of an in ovolo embryo rescue procedure for Hydrangea. J. Environ. Hort. 18:34-39.

Reed, S.M. 2004. Floral characteristics of a Hydrangea macrophylla $\times$ H. paniculata hybrid. Proc. Southern Nursery Assn. Res. Conf. 49:580-582.

Reed, S.M. 2005. Pollination biology of Hydrangea macrophylla. HortScience 40:335-338.

Reed, S.M., G.L. Riedel, and M.R. Pooler. 2001. Verification and establishment of Hydrangea macrophylla 'Kardinal' $\times H$. paniculata 'Brussels Lace' interspecific hybrids. J. Environ. Hort. $19: 85-88$. 
Rinehart, T.A., B.E. Scheffler, and S.M. Reed. 2006. Genetic diversity estimates for the genus Hydrangea and development of a molecular key based on SSR. J. Amer. Soc. Hort. Sci. 131:787-797.

Rohlf, F.J. 1992. NTSYS: pc numerical taxonomy and multivariate analysis system, version 1.70. Exeter Publ., Setauket, NY.

Shumei, H. and B. Bartholomew. 2001. Dichroa, p. 404-406. In: J. Pan, C. Gu, S. Huang, C. Wei, S. Jin, L. Lu, S. Akiyama, C. Alexander, B. Bartholomew, J. Cullen, R. Gornall, U. Hultgard,
H. Ohba, and D. Soltis (eds.). Flora of China. Vol. 8. 12 Mar. 2007. <http://flora.huh.harvard.edu/china/PDF/PDF08/DICHROA. pdf $>$.

Soltis, D.E., Q.-Y. Xiang, and L. Hufford. 1995. Relationships and evolution of Hydrangeaceae based on rbcL sequence data. Amer. J. Bot. 82:504-514.

Takeda, K., M. Kariuda, and H. Itoi. 1985. Blueing of sepal colour of Hydrangea macrophylla. Phytochemistry 24:2251-2254. 